\title{
Prevalence of cervical intraepithelial neoplasia \& cervical carcinoma in ever married women in rural area of a district in Haryana
}

\author{
Amandeep Kaur ${ }^{1 *}$, Anita Punia ${ }^{2}$, Mehar Singh Punia ${ }^{2}$, \\ Sunita Singh $^{3}$, Smiti Nanda ${ }^{4}$, Babita Jangra ${ }^{2}$
}

\author{
${ }^{1}$ Department of Community Medicine, Government Medical College, Haldwani, Nainital-263139, Uttarakhand, India \\ ${ }^{2}$ Department of Community Medicine, BPS Government Medical College for Women, Khanpur Kalan, Sonepat- \\ 131305, Haryana, India \\ ${ }^{3}$ Department of Pathology, Pt. B.D. Sharma PGIMS, Rohtak-124001, Haryana, India \\ ${ }^{4}$ Department of Department of Gynecology and Obstetrics, Pt. B.D. Sharma PGIMS, Rohtak-124001, Haryana, India
}

Received: 19 April 2015

Accepted: 08 May 2015

\author{
*Correspondence: \\ Dr. Amandeep Kaur, \\ E-mail: amansmailbox82@gmail.com
}

Copyright: (c) the author(s), publisher and licensee Medip Academy. This is an open-access article distributed under the terms of the Creative Commons Attribution Non-Commercial License, which permits unrestricted non-commercial use, distribution, and reproduction in any medium, provided the original work is properly cited.

\begin{abstract}
Background: Objectives: To find the burden of cervical intraepithelial neoplasia and cervical carcinoma in ever married rural women and to create awareness for its prevention and management.

Methods: The present cross-sectional study was undertaken in Block Beri, district Jhajjar, Haryana, among ever married females aged 30-59 years. A total of 1615 women were enumerated from three randomly selected subcenters. Out of these 1359 were interviewed by house to house survey. Among them 664 (49\%) consented for pervaginal examination for Visual Inspection with Acetic acid (VIA), Visual Inspection with Lugol's Iodine (VILI) and Papanicolaou (Pap) smear at the respective sub-centers. Data was analyzed using SPSS version 17.

Results: Per-vaginal discharge (45.9\%) was the most common complaint followed by lower backache $(36.6 \%)$ and lower abdominal pain $(35.0 \%$ ). VIA was positive in $18.5 \%$; while VILI in $23.2 \%$ of study subjects. On cytological examination, in 313 subjects, no significant pathology was detected. Six subjects $(0.904 \%)$ showed epithelial cell abnormality classified as ASCUS among four cases and one each as LSIL and HSIL.

Conclusions: Low prevalence $(0.9 \%)$ of epithelial cell abnormalities observed in study confirmed the national estimates for Haryana as low prevalence area for cervical cancers.
\end{abstract}

Keywords: CIN, Cervical carcinoma, Prevalence, Ever married women, Rural

\section{INTRODUCTION}

Cervical cancer is the third most common cancer in women, after breast and colorectal cancer, globally. More than $85 \%$ of the global burden occurs in developing countries. ${ }^{1}$ It contributes over 2.7 million years of life lost among women between the ages of 25 and 64 worldwide. $^{2}$ Cervical cancer kills more than 288000 women each year worldwide and disproportionately affects the poorest, the most vulnerable women. ${ }^{3}$
In India, it was estimated that 134420 new cases and 72825 deaths occurred in the year 2008 due to carcinoma cervix, accounting for nearly $25 \%$ of the global burden. The ASR (age-standardized incidence rate) of cervical cancer during 2008 was 27.0 per 100000 women in different regions of India.

The prevalence of cervical cancer in various regions of our country is mainly estimated ones from the various hospital registries. Community based studies are lacking in North India. Assessment of magnitude of any problem 
being the most basic and necessary component for any intervention, the present study was undertaken to find the burden of Cervical Intraepithelial Neoplasia (CIN) and cervical carcinoma in rural women of age 30-59 years and also to create awareness regarding various aspects of prevention and management of reproductive tract infections and cervical neoplasia.

\section{METHODS}

Study area: The study was undertaken in Block Beri, district Jhajjar, Haryana, a rural field practice area of department of Community Medicine Pt. Bhagwat Dayal Sharma PGIMS, Rohtak, from November 2011 to October 2012 having two CHCs, three PHCs, and 25 subcenters.

\section{Study design: Cross-sectional.}

Study subjects: Ever married females of age 30-59 years [4] who were residing in the study area for more than 6months and gave consent were included in the study. Women with the history of total hysterectomy or any operation on cervix and pregnant women were excluded.

Sample size: Taking the prevalence of $7.0 \%$ for cytologically reported CIN \& cervical cancers, ${ }^{5}$ with $20 \%$ allowable error at $95 \%$ confidence level, the calculated sample size was 1330 .

Data collection: From the study area, three sub-centers (total population 138 69) were chosen randomly using draw method. The women aged 30-59 years, residing in the study area for more than 6 months were enumerated to be 1615, using survey registers of sub-center and anganwadi centers. A survey of all the households was carried out and all the eligible women were contacted and purpose of the study was explained. Those who consented for participation in the study were interviewed using a semi-structured pre-tested questionnaire for socio-demographic and reproductive variables. Active support of the health workers and anganwadi workers of the respective areas, and interns posted at General Hospital Beri was taken. At least three revisits were paid to contact the absentees. Health Education about reproductive hygiene, prevention, early detection, and treatment of cervical cancer was imparted to all the available women.

The interviewed women were asked to come to the respective sub-centers on a prefixed date and time for per-vaginal examination, and the examination was done by the investigator herself with specialization in Gynecology \& Obstetrics. A unique serial number was given to each study woman and that was put on the questionnaire form, cytology form and the cytology slide (Papanicolaou/Pap smear). The attendance of the women was tallied with pre-filled questionnaires. The contact numbers of study women were noted for follow up.
Separate pre-sterilized Cusco's speculum, Ayre's spatula and swab were used for each woman. The perineum was cleaned with a wet swab and examined for any genital ulcer. Naked eye examination of cervix and vagina was done using LED torch light. The cervical smear specimen was collected using Ayre's spatula taking all aseptic precautions. Smear was made on a labeled slide and put in the Coplin's jar containing 95\% ethyl alcohol (fixative) for minimum 30 minutes for proper fixation. Visual inspection of the cervix was done after application of 5\% acetic acid (VIA) and then 5\% Lugol's iodine (VILI) using a sterilized swab-stick and results were noted as positive or negative ${ }^{6}$ on the prefilled Proforma. Fixed and air dried slides were put in a wooden box and were transported to the Department of Pathology for cytological examination along with filled cytology form. The slides were stained by Papanicolaou stain using standard techniques and results were reported according to the Bethesda System $2001^{7}$ and were made available within a week. Internal and external quality control measures were maintained in the pathology laboratories. The cytologists were blinded the VIA or VILI results. Prevalence was determined by Pap smear results. Privacy and confidentiality was maintained throughout the study.

The results were conveyed to the respective women. The women with positive Pap smear were especially contacted by the investigator and the report explained. They were then referred to Head, Department of Gynecology \& Obstetrics, PGIMS Rohtak for further investigations and management.

The women who were found to be suffering from vaginitis and/or cervicitis at the time of examination or as reported in cytopathological examination were given free treatment. These women were also motivated to adopt hygienic practices for future prevention of the problems.

Data analysis: The data so collected were coded, entered and compiled in MS Excel, and tabulated and analyzed using SPSS (version 17.0).

\section{RESULTS}

A total of 1615 women aged 30 to 59 years were enumerated from the selected sub-center survey registers. The details of study subjects are given in Figure 1.

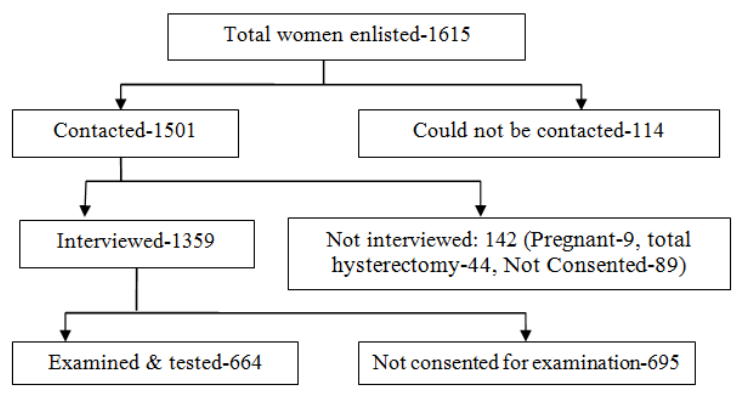

Figure 1: Showing details of study subjects. 
Socio-demographic profile: The mean age of women who were examined was $37.96 \pm 7.916$ years and the mean age of women who did not consent for the test was 40.77 \pm 8.493 years and the respective median age was 35 and 40 years. There was generalized refusal for vaginal examination among study subjects and it increased significantly with increasing age but it was not so for interviews. Jats and Brahmins $(67 \%)$ were the dominant community in the study area followed by scheduled caste $(26.5 \%)$ and backward class $(6.5 \%)$. Literacy level was $61.7 \%$ and refusal rate for vaginal examination was high among the illiterate as compared to literate women. Literacy status of husbands also followed the same response pattern for refusal.
Chief complaints: Per vaginal discharge was complained by $45.9 \%$ of 1359 women who were interviewed; but it was more $(53.5 \%)$ in women who consented for the test and $38.2 \%$ women who did not. Among women who were both interviewed \& tested, $40.7 \%$ complained of lower backache, $36.0 \%$ of lower abdominal pain, $30.0 \%$ of pruritus and $26.5 \%$ of burning sensation with micturition and increased frequency; the respective percentages for these complaints among only interviewed women were $32.2 \%, 34.0 \%, 16.5 \%$ and $22.9 \%$ (Table 1) and significantly less complaints might be one of the reasons for refusal for examination.

Table 1: Distribution of study population by Chief complaints**.

\begin{tabular}{|lllll|}
\hline Complaints & $\begin{array}{l}\text { Total } \\
\text { interviewed } \\
(\mathbf{N = 1 3 5 9 )}\end{array}$ & $\begin{array}{l}\text { Interviewed } \\
\text { \& tested } \\
(\mathbf{N}=664)\end{array}$ & $\begin{array}{l}\text { Interviewed } \\
\text { only } \\
(\mathbf{N}=695)\end{array}$ & P value \\
\hline Lower abdominal pain & $\begin{array}{l}475 \\
(35.0)\end{array}$ & $\begin{array}{l}239 \\
(36.0)\end{array}$ & $\begin{array}{l}236 \\
(34.0)\end{array}$ & 0.459 \\
\hline Lower backache & $\begin{array}{l}497 \\
(36.6)\end{array}$ & $\begin{array}{l}270 \\
(40.7)\end{array}$ & $\begin{array}{l}227 \\
(32.2)\end{array}$ & \multirow{2}{*}{$0.002 *$} \\
\hline Per vaginal discharge & $\begin{array}{l}624 \\
(45.9)\end{array}$ & $\begin{array}{l}355 \\
(53.5)\end{array}$ & $\begin{array}{l}269 \\
(38.2)\end{array}$ & $<0.001^{*}$ \\
\hline \multirow{2}{*}{ Pruritus } & 310 & $\begin{array}{l}199 \\
(30.0)\end{array}$ & $\begin{array}{l}111 \\
(16.0)\end{array}$ & $<0.001^{*}$ \\
\hline Burning micturition/Dysuria & $\begin{array}{l}334 \\
(24.6)\end{array}$ & $\begin{array}{l}176 \\
(26.5)\end{array}$ & $\begin{array}{l}158 \\
(22.7)\end{array}$ & 0.115 \\
\hline
\end{tabular}

*Statistically significant; **Multiple complaints (Figures in parentheses are percentages)

On examination: On per speculum examination it was found that discharge was present in $41.6 \%$ of the ladies and $33.4 \%$ had vaginitis. On naked eye examination of cervix, apparently normal cervix was found in $71.7 \%$ of women. Inflammation and/or erosion of cervix was present in $25.6 \%$, and $2.7 \%$ had the cervical polyps (Table 2).

Table 2: Distribution of study population by perspeculum examination findings.

\begin{tabular}{|lll|}
\hline Cervix-naked eye & $\begin{array}{l}\text { Frequency } \\
(\mathbf{n = 6 6 4 )})\end{array}$ & $\begin{array}{l}\text { Percentage } \\
(\%)\end{array}$ \\
\hline Apparently normal & 476 & 71.7 \\
\hline Inflammation/Erosion & 170 & 25.6 \\
\hline Polyps & 18 & 2.7 \\
\hline Bleeds to touch & 133 & 20.0 \\
\hline Discharge & 276 & 41.6 \\
\hline Vaginitis & 222 & 33.4 \\
\hline
\end{tabular}

Among the 355 ladies who complained of per vaginal discharge, discharge was found in only $190(53.5 \%)$ women on per-speculum examination, others (46.5\%) were mistaking normal discharge as abnormal. There were around $28 \%$ women who did not complain of per vaginal discharge but pathological discharge was found on per-speculum examination.

VIA was negative in $81.5 \%$ cases and positive in $18.5 \%$; while the respective percentages for VILI were $76.8 \%$ and $23.2 \%$ (Table 3 ).

Table 3: Distribution of study population by Visual Inspection findings.

\begin{tabular}{|lll|}
\multicolumn{1}{|c|}{} & $\begin{array}{l}\text { VIA } \\
(\mathrm{N}=664)\end{array}$ & $\begin{array}{l}\text { VILI } \\
(\mathrm{N}=664)\end{array}$ \\
\hline \multirow{2}{*}{ Negative } & $\begin{array}{l}541 \\
(81.5)\end{array}$ & $\begin{array}{l}510 \\
(76.8)\end{array}$ \\
\hline \multirow{2}{*}{ Positive } & $\begin{array}{l}123 \\
(18.5)\end{array}$ & $\begin{array}{l}154 \\
(23.2)\end{array}$ \\
\hline \multirow{2}{*}{ Total } & 664 & 664 \\
& $(100)$ & $(100)$ \\
\hline
\end{tabular}

(Figures in parentheses are percentages) 
Out of the total 664 smears taken, examined and reported as per Bethesda system of classification, in 313 smears, no significant pathology was detected. In 6 subjects $(0.904 \%)$ epithelial cell abnormality was detected, out of which there were four cases of Atypical Squamous Cell of Undetermined Significance (ASC-US) and one case each of Low-grade Squamous Intraepithelial Lesion (LSIL) and High-grade Squamous Intraepithelial Lesion (HSIL). Definite organisms were detected in 87 subjects (13.1\%). Cases of Bacterial vaginosis were $9.3 \%$, Trichomoniasis were $0.9 \%$, Fungal infections were $0.8 \%$, Koilocytic changes detected in $0.3 \%$, and $1.8 \%$ had mixed infections. Non-neoplastic changes in cervical epithelium were found in 245 study subjects. Among these most common was non-specific inflammation which was present in 114 women $(17.2 \%)$, followed by chronic cervicitis $(12.2 \%) \&$ inflammation induced atypia $(4.8 \%)$. Atrophic smear was present in $2.1 \%$ women and $0.6 \%$ had cervical erosion. Two percent slides were found to be unsatisfactory for examination due to inadequate sample because of atrophied cervices or due to too many inflammatory cells obscuring findings (Table 4).

Table 4: Distribution of study population by Pap smear findings.

\begin{tabular}{|c|c|c|}
\hline & $\begin{array}{l}\text { Frequency } \\
(n=664)\end{array}$ & Percentage \\
\hline \multicolumn{3}{|c|}{ No significant pathology - $313(47.1 \%)$} \\
\hline \multicolumn{3}{|c|}{ Epithelial cell abnormality - $6(0.904 \%)$} \\
\hline ASCUS* & 4 & 0.6 \\
\hline LSIL** & 1 & 0.2 \\
\hline HSIL $* * *$ & 1 & 0.2 \\
\hline \multicolumn{3}{|l|}{ Infections - 87 (13.1\%) } \\
\hline Bacterial vaginosis & 62 & 9.3 \\
\hline Trichomoniasis & 6 & 0.9 \\
\hline Candidiasis /Fungal & 5 & 0.8 \\
\hline Mixed infection & 12 & 1.8 \\
\hline Koilocytic $/ \mathrm{HPV}^{\#}$ changes & 2 & 0.3 \\
\hline \multicolumn{3}{|c|}{ Non-neoplastic changes - 245 (36.9\%) } \\
\hline Chronic cervicitis & 81 & 12.2 \\
\hline Cervical erosion & 4 & 0.6 \\
\hline Inflammation induced atypia & 32 & 4.8 \\
\hline Atrophic smear & 14 & 2.1 \\
\hline Non-specific inflammation & 114 & 17.2 \\
\hline \multicolumn{3}{|c|}{ Unsatisfactory for evaluation - $13(2.0 \%)$} \\
\hline Total & 664 & 100 \\
\hline
\end{tabular}

*ASC-US - Atypical squamous cell of undetermined significance,

**LSIL - Low-grade squamous intraepithelial lesion,

***HSIL - High-grade squamous intraepithelial lesion,

${ }^{\#} \mathrm{HPV}$ - Human papilloma virus

\section{DISCUSSION}

Cervical cancer kills 275000 women each year globally mainly women in the developing world and in the prime of their productive lives. ${ }^{1}$ The number of cases of cervical cancer has increased by $0.6 \%$ per year and the number of deaths from cervical cancer has increased by $0.46 \%$ per year, driven by increasing population sizes and population ageing, respectively. ${ }^{8}$

Out of the 1615 women enumerated, 664 (48.9\%) consented for per-speculum examination and tests (Figure 1). The consent for per-speculum examination or refusal was not random but was influenced by various sociodemographic and other variables. In a study conducted by Bhatla et al. ${ }^{9} 59.4 \%$ women participated (range, $41 \%$ $91 \%$ ) in the screening for cervical cancer. The lower age limit and incentives of the project could have been the reasons for comparatively lesser refusal rate. The present study was self-financed and there was no provision of such incentive. Hence, relatively low consent rate is justified. Moreover, the examination was done by the specialist investigator single-handedly, so the probability of valid observations and uniformity is high.

The response rate for both the interview and the test was highest in the age group of 30-34 years, and it decreased with increasing age. The reason of refusal given by elderly ladies, who were above 50 years of age, was that they don't require the test at this age as they have a few years to live, they do not want to create doubt of any disease in their minds. The other reasons for refusal were: no symptom/problem at present, shyness/embarrassment and un-comfort related with the test, fear of the procedure, the test might cause some other problem, and the fear of the diagnosis that is usually associated with a taboo. Aswathy et al. ${ }^{10}$ identified similar factors for nonscreening for cervical cancer where only $30 \%$ women expressed their desire for undergoing screening tests. Meszaros $E^{11}$ too found similar barriers to cervical cancer screening among the elderly women. It is important to motivate them through village level health functionaries to make them understand that such minor procedures may help to add life to years.

Positive response for undertaking the per-speculum examination was noticeably low among illiterate women and also among those whose husbands were illiterate and it increased with increase in the educational status of spouses. Therefore, IEC activities should also be directed towards both, the female and the male members of the society if a sustainable change is really desired.

The most common complaint among the total 1359 females interviewed was that of excessive per-vaginal discharge $(45.9 \%)$, and the complaint was significantly higher among women who got themselves tested $(53.5 \%$ among those who consented and $38.2 \%$ in others) (Table 2). Singla et al. ${ }^{12}$ and Ghosh et al. ${ }^{13}$ too reported discharge per vagina as the most common complaint seen in women.

Cervix was observed as apparently normal in $71.7 \%$ of the ladies examined; inflammatory changes were detected in $25.6 \%$ and cervical polyps with no associated inflammation in $2.7 \%$ (Table 2). Ghosh et al. ${ }^{13}$ found 
normal looking cervix in $44.3 \%$ in their study. The number of abnormal cervices could have been more because that was a hospital based study.

Out of the 664 women interviewed \& tested, VIA was found to be positive in $18.5 \%$ women and VILI was positive in $23.2 \%$ (Table 3 ). Some pathology was detected in more than half of the ladies in Pap smear examination: Non-neoplastic cellular changes $36.9 \%$, and epithelial cell abnormalities in $6(0.9 \%)$ cases consisting of 4 ASCUS, 1 LSIL and 1 HSIL (Table 4). Singla et al. ${ }^{12}$ in a hospital-based cross-sectional study found similar findings for VIA and VILI; but the proportion of Pap smear results was much higher, which is expected in a hospital based study. Differences in findings were also observed in the results of studies conducted by Ghosh et al. ${ }^{13}$ and Bhatla et al. ${ }^{9}$ The variation of the results could be due to small sample size and subjective variations in interpretation of results.

In our study, specific organism was reported in 87 $(13.1 \%)$ smears. Out of these, $62(9.3 \%)$ were Bacterial vaginosis, $6(0.9 \%)$ Trichomoniasis, $5 \quad(0.8 \%)$ Candidiasis, $12(1.8 \%)$ mixed infections and $2(0.3 \%)$ koilocytic changes (Table 4). Vecchia et al. ${ }^{14}$ and Klomp et al. ${ }^{15}$ have emphasized that clinical histories of several sexually transmitted diseases were found to be positively associated with the risk of intraepithelial neoplasia. Therefore, we can say that these infections too cannot be overlooked. Streamlined control measures are required to reduce the burden of the disease.

The present community based study was also an effort towards creating awareness about one of the common cancers of women as it was evident from the study also that there is a need to make women aware about the seriousness of the problem and also about the early signs and symptoms, so that they themselves come forward in the early stages. Information about the early signs and symptoms of the common cancers and their associated risk factors can be stressed upon in trainings provided to grass-root level health workers who can act as motivators and educators for the rural women.

\section{Strengths of the study}

1. The present study was community based and truly covered the randomly sampled whole population and thus, results are valid for the entire population.

2. Investigator herself is a specialist in Gynecology and Obstetrics. She collected data and performed examination herself single handedly in the community. So, the probability of valid observations and uniformity is high. Senior consultant pathologist and the Head of Gynecology and Obstetrics department themselves personally performed tests and management at PGIMS Rohtak, a tertiary care institution and were involved fully as co-supervisors in the study. Hence, results of the study are authentic and valid from all aspects.
3. Our study confirms the estimates for Haryana as a low prevalence area for cervical cancer.

\section{Weaknesses of the study}

1. Comparatively small sample size for a low prevalence area.

2. Relatively high refusal rate $(51 \%)$ among women for per speculum examination and tests. But keeping in view the socio-cultural milieu in rural areas, the consent rate of $49 \%$ was a remarkable achievement in community settings. Moreover, after considering the practically similar age distribution among those who refused and those who consented for examination, it was concluded that the prevalence of epithelial cell abnormalities would have remained approximately $0.9 \%$ even if all the women would have consented for the tests.

\section{Synopsis}

Low prevalence $(0.9 \%)$ of epithelial cell abnormalities was observed which confirms Haryana as low prevalence area for cervical cancers.

Funding: No funding sources

Conflict of interest: None declared

Ethical approval: The study was approved by the institutional ethics committee

\section{REFERENCES}

1. Farley J, Shin HR, Bray F, Forman D, Mathers C, Parkin DM. GLOBOCAN 2008: Cervical cancer incidence and mortality worldwide in 2008. In: Farley J, Shin HR, Bray F, Forman D, Mathers C, Parkin DM, eds. IARC CaseBase 10. Lyon, France: IARC Press; 2010.

2. Yang BH. Cervical cancer as a priority for prevention in different world regions: an evaluation using years of life lost. Int J Cancer. 2004;109:41824.

3. IARC Screening Group. Cervical cancer. WHO, 2012. Available at: http://screening.iarc.fr/cervicalindex.php.

4. Basu P, Chowdhury D. Cervical cancer screening \& HPV vaccination: a comprehensive approach to cervical control. Indian J Med Res. 2009;130:241-6.

5. Sankaranarayanan R, Nene BM, Dinshaw KA, Mahe C, Jayant K, Shastri SS, et al. A cluster randomized controlled trial of visual, cytology and human papilloma virus screening for cancer of the cervix in rural India. Int J Cancer. 2005;116:617-23.

6. Sankaranarayanan R, Wesley RS. A practical manual on visual screening for cervical neoplasia. Lyon, France: IARC Press; IARC technical publication Number 41, 2015. Available at: press@iarc.fr.

7. IARC. IARC handbooks of cancer prevention. Cervix cancer screening. Vol. 10. Lyon, France: International Agency for Research on Cancer Press; 
2005.

Available

http://www.iarc.fr/en/publications/pdfs-

online/prev/handbook10/index.php.

8. Forouzanfar MH, Foreman KJ, Delossantos AM, Lozano R, Lopez AD, Murray CJL, et al. Breast and cervical cancer in 187 countries between 1980 and 2010: a systematic analysis. Lancet. 2011;378:146184.

9. Bhatla N, Gulati A, Mathur SR, Rani S, Anand K, Muwonge R, et al. Evaluation of cervical screening in rural North India. Int $\mathbf{J}$ Gynaecol Obstet 2009; 105:145-9.

10. Aswathy S, Quereshi MA, Kurian B, Leelamoni K. Cervical cancer screening: current knowledge \& practice among women in a rural population of Kerala, India. Indian J Med Res. 2012;136:205-10.

11. Meszaros E. Risk factors, knowledge, and beliefs about cervical cancer screening and screening practices among Appalachian women. In: Meszaros E, eds. A Thesis. Ohio: The Ohio State University; 2006.

12. Singla S, Mathur S, Kriplani A, Agarwal N, Garg P, Bhatla N. Single visit approach for management of cervical intraepithelial neoplasia by visual inspection \& loop electrosurgical excision procedure. Indian $\mathbf{J}$ Med Res. 2012;135:614-20.

13. Ghosh P, Gandhi G, Kochhar PK, Zutshi V, Batra S. Visual inspection of cervix with Lugol's iodine for early detection of premalignant \& malignant lesions of cervix. Indian J Med Res. 2012;136:265-71.

14. Vecchia CL, Francesch S, Decarli A, Fasoli M, Gentile A, Parazzini F, et al. Sexual factors, venereal diseases, and the risk of intraepithelial and invasive cervical neoplasia. Cancer. 1986;58:935-41.

15. Klomp JM, Boon ME, Van Haaften M, Heintz PM. Cytologically diagnosed Gardnerella vaginalis infection and cervical (pre)-neoplasia as established in population-based cervical screening. Am J Obstet Gynecol. 2008;199:480.e1-5.

DOI: 10.18203/2320-1770.ijrcog20150098

Cite this article as: Kaur A, Punia A, Punia MS, Singh S, Nanda S, Jangra B. Prevalence of cervical intraepithelial neoplasia \& cervical carcinoma in ever married women in rural area of a district in Haryana. Int J Reprod Contracept Obstet Gynecol 2015;4:814-9. 